\title{
Assessment of pharmacognostical characters of the stem bark of Stereospermum colais buch
}

\author{
Mohammed Imran ${ }^{1}$, Yogesh Sonawane ${ }^{2}$, Rashid Akhtar ${ }^{3}$, Sufiyan Ahmed ${ }^{4}$ \\ 'Department of Pharmaceutical Chemistry, KBHSST'S Institute of Pharmacy, Malegaon, Maharashtra, India, ${ }^{2}$ Department of Pharmaceutical Chemistry, National Institute of \\ Pharmaceutical Education and Research, Mohali, Punjab, India, ${ }^{3}$ Department of Pharmacognosy, KBHSST’S Institute of Pharmacy, Malegaon, Maharashtra, India, ${ }^{4}$ Department \\ of Pharmacognosy, Gangamai College of Pharmacy, Nagaon, Dhule, Maharashtra
}

Correspondence:

Dr. Mohammed Imran, Department of Pharmaceutical Chemistry, KBHSST'S Institute of Pharmacy, Malegaon, Maharashtra, India.

E-mail: imransa99@rediffmail.com

\begin{abstract}
To study detail pharmacognostical profile of stem bark of Stereospermum colais. Assessment of pharmacognostical micro and macroscopical characters of fresh and dried stem bark samples were analyzed. WHO recommended parameter was utilized for investigation of physiochemical studies and fluorescent characters of the stem bark samples were also tested. The stem bark is woody shrub aboriginal to Asian country. It is straight stemmed deciduous tree $18-30 \mathrm{~m}$ in height $2.8 \mathrm{~m}$ in girth. Stem bark shows fractures on its outer surface and inner side shows light yellowish shade. Stem bark shows layer of epidermis, underneath this lies 2-4 rows of parenchyma with rounded or arc-shaped vascular bundles, lignified tissue, pericyclic non-lignified fibers, mucilage cells and 5-6 rows of longitudinal and 5-6 rows of tangential stone cells. The results of the study can carry as a valuable source of information and provide suitable standards for identification of this plant material in future investigations and applications.
\end{abstract}

Keywords: Macroscopy, microscopy, pharmacognosy, phloem and physicochemical, stem bark, Stereospermum colais, xylem

\section{Introduction}

Stereospermum colais (Buch.-Ham.ex Dillw) is most widely known as Trumpet flower tree and yellow snake in English and Padri in Hindi, belonging to the family of Bignoniaceae. It is found in moist regions of India, flowers and fruits are appears during March-July. All part of tree are used in many uses such as diarrhea, cough, asthma, bleedings, hyperacidity, vomiting, fever, general debility, rheumatism, malarial fever, wounds, burning sensation, heart disease, antidiabetic, antiperoxidative and radical scavenging activities of this species have not been assessed, and its chemical composition is scarcely known. ${ }^{[1]}$ Mostly used of this plan as therapeutical agent to treat diabetes, heart disease and various other diseases has been suggested by present research. The leaves of S. colais was investigated well previously by other workers for phytochemistry and pharmacological activity. But quite a few references

\section{Access this article online}

Website: http://www.jpbs-online.com E-ISSN: 2321-0125

How to cite this article: Sonawane Y, Imran M, Akhtar $\mathrm{R}$, Ahmed S. Assessment of pharmacognostical characters of the stem bark of Stereospermum colais buch. J Pharm BioSci 2017;5(2):10-13.

Source of Support: Nil, Conflict of Interest: None declared.

are available regarding the phytochemicals present in other part of the plant. Hence the objective of the present investigation is to evaluate various pharmacognostical parameters such as macroscopic, microscopy, physicochemical, fluorescence and phytochemical studies of the plant.

\section{Materials and Methods}

The stem bark of S. colais plant was collected from the Patnur Ghat, Nanded district (Maharashtra), India in the month of July. The plant was identified by Dr. Arvind S Dhabe, Department of Botany, Dr. Babasaheb Ambedkar Marathwada University, Aurangabad (Maharashtra), India.

\section{Pharmacognostical study}

Fresh stem barks were taken for morphological and histological studies. Coarse powder (60\#) was used to study macroscopical characters, physicochemical parameters and phytochemical investigation. For the microscopical studies, transverse sections of stem bark was prepared and stained as per standard procedure. ${ }^{[2,3]}$ The powder microscopy was performed according to the method of Khandelwal. ${ }^{[3]}$

\section{Physicochemical and phytochemical analysis}

Investigation of physicochemical values such as percentage of ash values and extractive values are showed in Table 1, were determined according to the well-established official method and procedure..$^{[4,5]}$ 
Preliminary screening was carried out using the standard procedure described by Khandelwal. ${ }^{[3]}$

\section{Fluorescence analysis}

Powdered of stem bark material was treated with various chemical reagents and exposed to visible, ultraviolet (UV) light (short UV) to study their fluorescence behavior as showed in Table 2. ${ }^{[6,7]}$

\section{Results}

\section{Macroscopic characteristics}

The stem bark is woody shrub aboriginal to Asian country. It is straight stemmed deciduous tree $18-30 \mathrm{~m}$ in height $2.8 \mathrm{~m}$ in girth. ${ }^{[1]}$ Stem bark shows fractures on its outer surface and inner side shows light yellowish shade (Figure 1).

\section{Microscopical characteristics}

\section{Stem bark}

Stem bark shows layer of epidermis (Figure 2) and fragments of parenchyma, palisade cells, and fragments of epidermal cells underneath this lies 2-4 rows of parenchyma with rounded or arcshaped vascular elements (Figures 3 and 4), lignified tissue (Figure 5), pericyclic non-lignified fibers (Figure 6), mucilage cells and 5-6 rows of longitudinal and powder characteristics showing part 5-6 rows of tangential stone cells (Figure 7).

\section{Preliminary phytochemical screening}

Methanolic extract obtained by cold maceration of powder of stem bark of $S$. colais and subjected to the preliminary phytochemical screening of stem bark mainly revealed the presence of alkaloid, tannin, terpenoids, saponins, tannins and flavonoids.

Table 1: Physiochemical parameters

\begin{tabular}{lc} 
Physiochemical parameter & Result \\
\hline $\mathrm{pH}(1 \%$ solution $)$ & 5.7 \\
LOD & $7.8 \% \mathrm{w} / \mathrm{w}$ \\
Ash content & $7.67 \% \mathrm{w} / \mathrm{w}$ \\
Density & $0.403 \mathrm{~g} / \mathrm{ml}$ \\
Water soluble extract & $21.4 \% \mathrm{w} / \mathrm{w}$ \\
Alcohol soluble residue & $11.8 \% \mathrm{w} / \mathrm{w}$ \\
\hline LOD: Loss on drying &
\end{tabular}

Table 2: Fluorescence analysis of stem bark of S. colais

\begin{tabular}{lll} 
Fluorescence study & Long UV light & Short UV light \\
Powder as such & Yellow & Greenish \\
Powder in distilled water & Yellow & Yellowish green \\
Powder in absolute alcohol & Yellowish green & Green \\
Powder in $10 \% \mathrm{NaOH}$ & Green & Yellow \\
Powder in $10 \% \mathrm{HNO}_{3}$ & Green & Green \\
Powder in $50 \% \mathrm{H}_{2} \mathrm{SO}_{4}$ & Green & Light green \\
Powder in $10 \% \mathrm{HCL}$ & Dark green & Dark green \\
\hline
\end{tabular}

S. colais: Stereospermum colais, UV: Ultraviolet

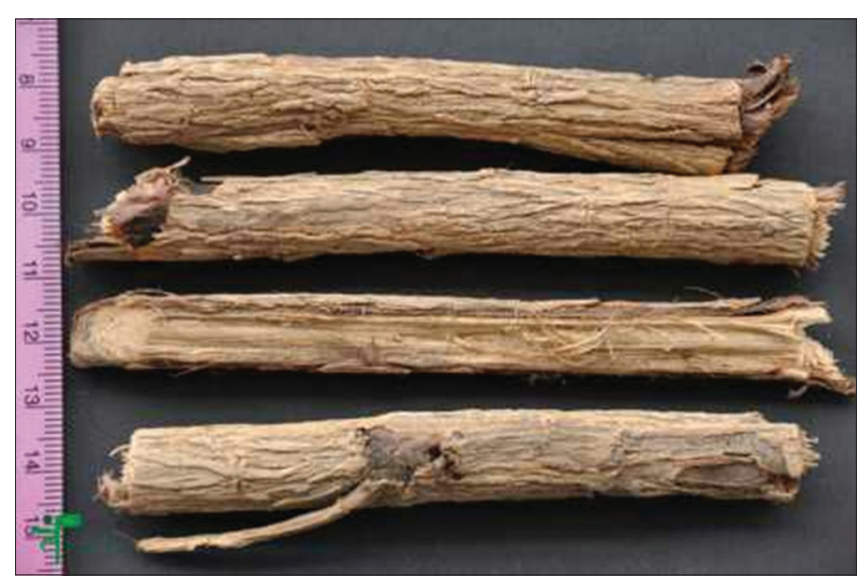

Figure 1: Dried stem bark of Stereospermum colais showing morphology

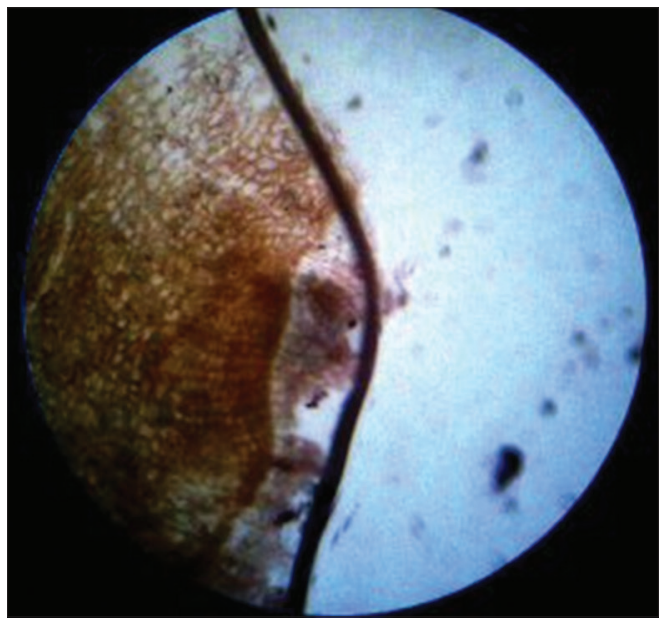

Figure 2: Transverse section of stem bark stained with ruthenium red showing epidermis

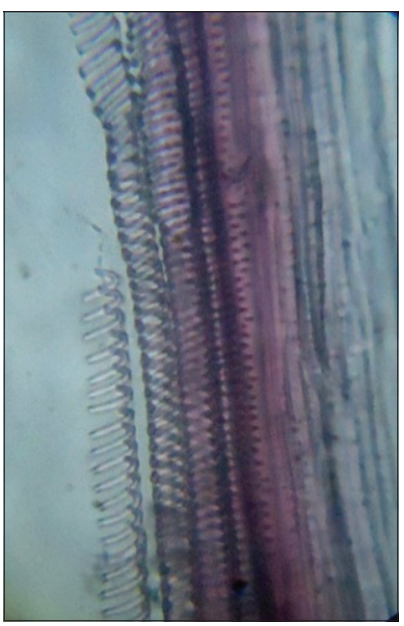

Figure 3: Powder characteristics showing vascular elements

\section{Physicochemical study}

Physicochemical parameter were analysis of stem bark such as foreign organic matter, loss on drying, swelling index, ash value and extractive value are presented in Table 1 . The fluorescence analysis of $S$. colais stem bark under day light and UV (short, $254 \mathrm{~nm}$ ) light is recorded in Table 2. 


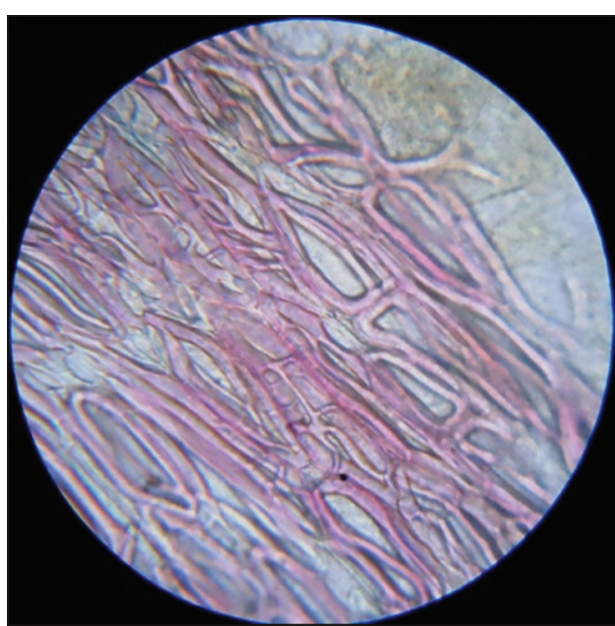

Figure 4: Vascular elements

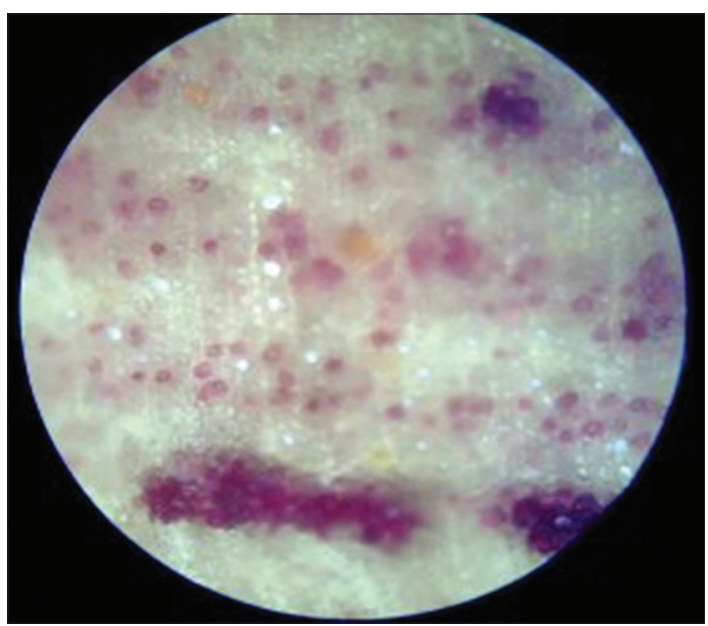

Figure 5: Transverse section of stem bark shows the lignified tissue

\section{Discussion}

This study can be concluded that the stem bark of plant $S$. colais is used for various purpose such as antidiabetes, analgesic, antibacterial, antifungle, antiperoxidative and radical scavenging, so the present study was designed to investigate the microscopical characteristics, phytoconstituent of this plant.

Ethnomedically, the stem bark of this plant were used by local people in the treatment of various disease conditions without standardization. The standardization of a crude drug is an integral part for establishing its correct identity. ${ }^{[8]}$ Before any crude drug can be included in an herbal pharmacopoeia, pharmacognostic parameters and standards must be established. Microscopic method is one of the simplest and cheapest methods to start with for establishing the correct identity of the source materials. ${ }^{[9,10]}$

The pharmacognostic standards for stem bark of S. colais are carried out for the first time in this study. The macroscopical characters of the stem can serve as diagnostic parameters. Parenchymatous cells

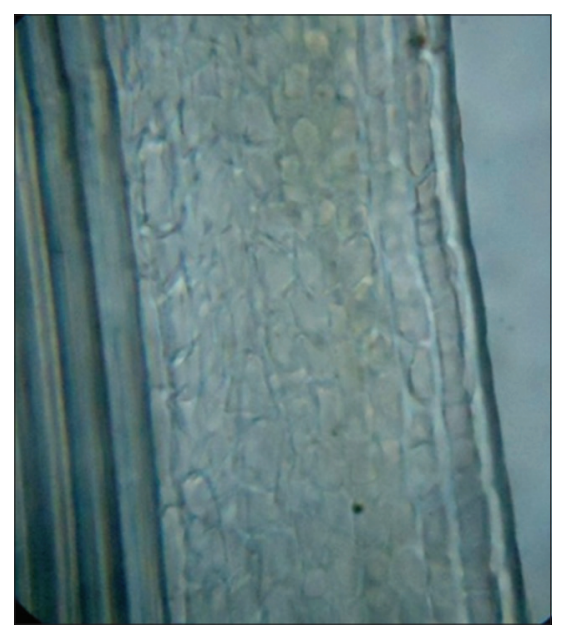

Figure 6: Longitudinal sections showing non-lignified pericyclic fibers

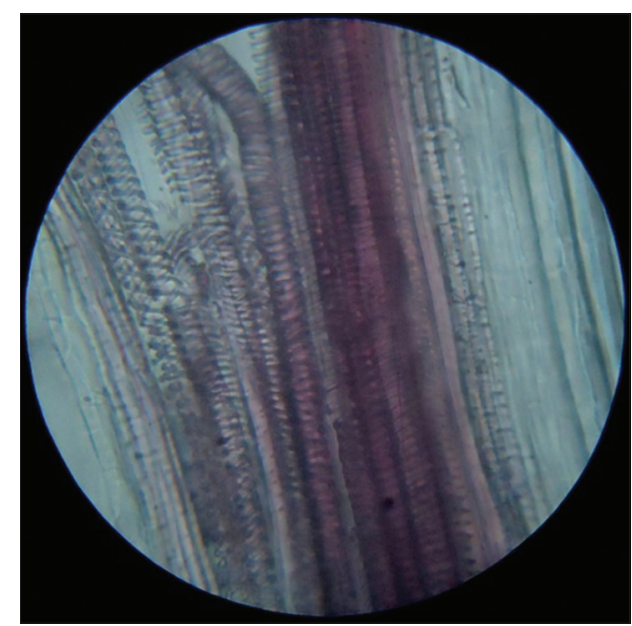

Figure 7: Powder characteristics showing stone cells

containing pigment, mesocarp embedded with rounded or arcshaped vascular bundles, pericyclic non-lignified fibers, mucilage cells and stone cells. These studies help in the identification of the plant materials. ${ }^{[1]}$ Ash values and extractive values can be used as reliable aid for detecting adulteration. These studies help in the identification of the plant materials. ${ }^{[1]}$ Ash values of drug give an idea of earthy matter or the inorganic composition and other impurities present along with drug. Extractive values are primarily useful for the determination of exhausted and adulterated drugs. ${ }^{[8]}$ Extractive values are also useful to evaluate the chemical constituents present in the crude drug and also help in estimation of specific constituents soluble in particular solvents. ${ }^{[12,13]}$ The fluorescent analysis under day light and UV light by treatment with different chemical reagents showed different color. This analysis suggests that, stem bark of $S$. colais probably contain active agent and this provides the basis for their folkloric use as a cure for some human ailments.

In conclusion, these parameters which are being reported for the first time could be useful in setting some diagnostic indices for the identification and preparation of a monograph of the S. colais plant. 


\section{Acknowledgments}

Authors thank, KBHSST's Institute of Pharmacy Malegaon, for providing facilities to conduct of this interested research work.

\section{References}

1. Prema S, Saraswathi A, Chitra K, Gopal V. A review on Stereospermum colais Mabb: Bignoniaceae. Int J Pharm Sci Rev Res 2013;53:314-7.

2. Brain KR, Turner TD. The Practical Evaluation of Phytopharmaceuticals. Bristol: Wright-Scientechnica; 1975. p. 4-9.

3. Khandelwal KR. Practical Pharmacognosy. $19^{\text {th }}$ ed. Pune: Nirali Publication; 2008. p. 149-64.

4. Ministry of Health and Welfare. Indian Pharmacopeia. $4^{\text {th }}$ ed. New Delhi: Government of India, Ministry of Health and Welfare, Controller of Publications; 1996. p. A53-4.

5. WHO. Quality Control Methods for Medicinal Plant Material. Geneva:WHO; 1992. p. 22-34.

6. Edwin S, Joshi SB, Jain DC. Comparative pharmacognostic studies on root powder of Plumbago zeylanica and Plumbago rosea. Indian J Nat Prod 2008;2:27-9.

7. Chase CR Jr, Pratt R. Fluorescence of powdered vegetable drugs with particular reference to development of a system of identification. J Am Pharm Assoc Am Pharm Assoc 1949;38:324-31.

8. Pandya DJ, Desai TR, Nadpara NP, Mehta HA, Modi AM. Pharmacognostic study and establishment of quality parameters of leaves of Bombax insigne Linn. Int J Pharmacogn Phytochem Res 2010;2:1-5.

9. Singh S, Machwal L, Chauhan MG. Pharmacognostic study of male leaves of Trichosanthes dioica Roxb. With special emphasis on microscopic technique. J Pharmacogn Phytother 2010;2:71-5.

10. Bragadeshwaran S, Thangarag S, Rajiv CR, Balaji D. Pharmacological and biomedical properties of sea anemones Paracondactylis indicus, Paracondactylis senensis, Heteractis magnifica and Stichoactyla haddoni from East Coast of India. Asian Pac JTrop Med 2011;4:722-6.

11. Nayak SB, Patel KN. Pharmacognostic studies of the Jatropha curcas leaves. Int J Pharm Tech Res 2010;2:140-3.

12. Thomas S, Patil DA, Patil GA, Chandra N. Pharmacognostic evaluation and physicochemical analysis of Averroha carambola L. Fruit. J Herb Toxicol 2008;2:51-4.

13. Kumar S, KumarV, Prakash OM. Pharmacognostic study and anti-inflammatory activity of Callistemon lanceolatus leaf. Asian Pac J Trop Biomed 2011;1:177-81. 